\title{
Diagnostic Value of the Nuclear Matrix Protein 22 Test and Urine Cytology in Upper Tract Urothelial Tumors
}

\author{
M. Jovanovic ${ }^{a} \quad$ I. Soldatovic ${ }^{b} \quad$ A. Janjic ${ }^{a} \quad$ A. Vuksanovic ${ }^{a} \quad$ Z. Dzamic ${ }^{a}$ \\ M. Acimovic ${ }^{a} \quad$ J. Hadzi-Djokic ${ }^{a}$ \\ a Urology Clinic, Clinical Center of Serbia, and ${ }^{b}$ Department of Biostatistics and Research in Medicine, \\ School of Medicine, University of Belgrade, Belgrade, Serbia
}

\section{Key Words}

Nuclear matrix protein $22 \cdot$ Cytology $\cdot$ Upper urothelial tumor

\begin{abstract}
Objective: To investigate the diagnostic value of the nuclear matrix protein 22 (NMP22) test in comparison to urine cytology for the detection of upper tract urothelial carcinoma. Patients and Methods: Patients with transitional cell carcinoma of the upper urinary tract $(n=34)$ and patients with renal calculosis $(n=25)$ were included in this study. Voided urine samples and separated catheter urine specimens were assayed for NMP22 and cytological examination. Results: The sensitivity of the NMP22 test in separated and voided urine was 73.2 and $70.5 \%$, respectively, compared to 64.7 and $58.8 \%$ of urine cytology. The specificity of the NMP22 test in separated and voided urine was 88 and $92 \%$, respectively, compared to 96 and $96 \%$ of urine cytology. The combination of separated and voided urine is the best method because the sensitivity is $79.41 \%$ and specificity $88 \%$. There is a high agreement of the NMP22 test in voided and separated urine (kappa $=0.795, \mathrm{p}<0.01$ ), indicating that the voided urine is adequate for diagnosis. Conclusions: The NMP22 test has higher sensitivity but lower specificity than cytology. The combination of these two tests could be a very useful diagnostic method for detection of upper urothelial tumors.
\end{abstract}

Copyright $\odot 2011$ S. Karger AG, Basel

\section{KARGER}

Fax +41613061234 E-Mail karger@karger.ch www.karger.com
(C) 2011 S. Karger AG, Basel

$0042-1138 / 11 / 0872-0134 \$ 38.00 / 0$

Accessible online at:

www.karger.com/uin

\section{Introduction}

The nuclear matrix protein 22 (NMP22) test is a noninvasive method for the detection of protein level of nucleus mitotic apparatus (nuclear mitotic apparatus protein, NuMA) in urine sample. Healthy people usually have a very small amount of NMP in their urine, while it is specific to the transitional epithelial cells in the urinary tract. Transitional cell carcinoma (TCC) cells contain up to 80 times higher concentration of NMP than normal cells, and it is released in the urine after cell death. It has been reported that patients with TCC of the bladder have a higher concentration of NMP22 in the urine compared to healthy controls. The studies show test specificity of over $90 \%$ with the sensitivity values even up to $90 \%$ for T2 stage of bladder carcinoma, whereas combining the NMP22 test with cystoscopic examination increases the overall rate of bladder cancer detection up to 96\% [1-4]. Based on the previous studies, the result of the NMP22 tests with protein level above $10 \mathrm{U} / \mathrm{ml}$ in urine is associated with high probability of the presence of TCC. Bladder check NMP22 test is a rapid immunochromatography analysis that is designed to identify urine samples with NMP22 concentration greater than $10 \mathrm{U} / \mathrm{ml}$. Since the same epithelial cells line the bladder and the upper urinary tract (UUT), it could be hypothesized that the increased concentration of the NMP occurs in the urine of patients with upper tract urothelial carcinoma. There- 
fore, the diagnostic and prognostic value of the NMP22 test in UUT carcinoma remains to be assessed.

The purpose of this trial was to evaluate the diagnostic value of the NMP22 test in separated and voided urine of patients with diagnosed UUT carcinoma and to compare the NMP22 test with the diagnostic value of urine cytology. Also, the association of the NMP22 test with clinical and pathohistological characteristics of UUT carcinoma was analyzed.

\section{Patients and Methods}

Study Patients

The study included 34 patients with upper tract urothelial carcinoma in various disease stages treated at the Urology Clinic of the Clinical Center of Serbia from 2005 to 2009. All patients underwent complete diagnostic procedures which included laboratory analyses, ultrasound examination, X-ray, IVP, retrograde pyelography, ureterorenoscopy and CT if needed to establish extracapsular extensions. Two samples of urine were taken from each patient, the first total voided urine and the other separated urine obtained by ureteral catheterization of the diseased UUTs. Both samples were assayed by the NMP22 test and urine cytology. The control group consisted of 25 patients with the diagnosis of renal calculosis who were planned to be treated by extracorporeal shock wave lithotripsy. Controls have been examined by ultrasonography, X-ray and IVP to exclude the presence of malignant disease. Urine samples from the control subjects were collected and analyzed in the same way as the samples from TCC patients.

\section{Statistical Analyses}

All computations were performed with the Statistical Package for Social Sciences release 12.0. Sensitivity was defined as the number of true positive UUT cancer cases classified as positive by a test. Specificity was defined as the number of true negative cases classified as negative by a test. The positive predictive value of a test was defined as the probability that the patient had UUT cancer, given the test was positive. The negative predictive value of a test was defined as the probability that the patient was free of UUT cancer, given the test was negative. The kappa test was used for agreement.

\section{Results}

\section{Patient Characteristics}

The average age of 34 patients with UUT carcinoma (22 patients with pyelon and/or calix tumor and $12 \mathrm{pa}-$ tients with tumors of the ureter) was $63.4 \pm 6.2$ years, while the average age of the control group of 25 patients (17 with pyelon calculosis and 8 with calix calculosis) was $45.3 \pm 7.8$ years. Out of 34 patients with tumors of the UUT, 12 patients $(36 \%)$ were females. The control group consisted of $14(63 \%)$ women and $8(27 \%)$ men.

Diagnostic Value of NMP22 and Urine

Cytology in UUT Carcinoma
Table 1. The NMP22 test in relation to the diagnosis of UUT carcinoma

\begin{tabular}{lcrc}
\hline \multirow{2}{*}{ Diagnostic test } & & \multicolumn{2}{c}{ UUT tumor } \\
\cline { 2 - 4 } & & no & yes \\
\hline \multirow{2}{*}{ NMP22 in separated urine } & - & 22 & 9 \\
& + & 3 & 25 \\
\hline NMP22 in voided urine & - & 23 & 10 \\
& + & 2 & 24 \\
\hline Cytology, separated urine & - & 24 & 12 \\
& + & 1 & 22 \\
\hline \multirow{2}{*}{ Cytology, voided urine } & - & 24 & 14 \\
& + & 1 & 20 \\
\hline
\end{tabular}

Table 2. Overall sensitivity (Sn), specificity (Sp), positive predictive value (PPV), and negative predictive value (NPV)

\begin{tabular}{lllll}
\hline Diagnostic test & Sn, \% & Sp, \% & PPV, \% & NPV, \% \\
\hline NMP22, separated urine & 73.5 & 88 & 89.2 & 70.9 \\
NMP22, voided urine & 70.5 & 92 & 92.3 & 69.6 \\
Cytology, separated urine & 64.7 & 96 & 95.6 & 66.6 \\
Cytology, voided urine & 58.8 & 96 & 95.2 & 63.1 \\
Combination separated urine $^{1}$ & 79.4 & 88 & 90 & 75.8 \\
Combination voided urine $^{1}$ & 79.4 & 88 & 90 & 75.8 \\
\hline
\end{tabular}

${ }^{1}$ NMP22 or cytology positive.

\section{The NMP22 Test and Urine Cytology in Relation to} the Diagnosis of UUT Tumor

Distribution of patients with UUT carcinoma and control subjects in relation to the positive or negative NMP22 test results and cytology in separated and voided urine is presented in table 1.

Sensitivity, Specificity, Positive Predictive Value, and Negative Predictive Value of the Urine NMP22

Test and Cytology in Separated and Voided Urine in

Detecting UUT Carcinoma

Analyzing the sensitivity of the studied methods, it was found that the highest sensitivity of NMP22 is in the separated urine, followed by voided urine. The sensitivity of urine cytological analyses was lower. However, the specificity of cytology was higher compared to NMP22. The combination of NMP22 and cytology (one or both positive tests) has the highest sensitivity but lower specificity than cytology alone. The results are shown in table 2. 
Table 3. Stage and grade of UUT carcinoma in relation to the NMP22 test and urine cytology

\begin{tabular}{|c|c|c|c|c|c|c|c|c|}
\hline \multirow[t]{2}{*}{ UUT tumor } & \multicolumn{2}{|c|}{$\begin{array}{l}\text { NMP22 } \\
\text { separated } \\
\text { urine }\end{array}$} & \multicolumn{2}{|c|}{$\begin{array}{l}\text { NMP22 } \\
\text { voided } \\
\text { urine }\end{array}$} & \multicolumn{2}{|c|}{$\begin{array}{l}\text { Cytology } \\
\text { separated } \\
\text { urine }\end{array}$} & \multicolumn{2}{|c|}{$\begin{array}{l}\text { Cytology } \\
\text { voided } \\
\text { urine }\end{array}$} \\
\hline & - & + & - & + & - & + & - & + \\
\hline \multicolumn{9}{|l|}{ Stage } \\
\hline $\mathrm{Ta}(\mathrm{n}=8)$ & 5 & 3 & 5 & 3 & 6 & 2 & 7 & 1 \\
\hline $\mathrm{T} 1(\mathrm{n}=8)$ & 2 & 6 & 2 & 6 & 3 & 5 & 4 & 4 \\
\hline $\mathrm{T} 2(\mathrm{n}=4)$ & 1 & 3 & 1 & 3 & 2 & 2 & 2 & 2 \\
\hline $\mathrm{T} 3(\mathrm{n}=13)$ & 1 & 12 & 2 & 11 & 1 & 12 & 1 & 12 \\
\hline $\mathrm{T} 4(\mathrm{n}=1)$ & 0 & 1 & 0 & 1 & 0 & 1 & 0 & 1 \\
\hline \multicolumn{9}{|l|}{ Grade } \\
\hline $\mathrm{GI}(\mathrm{n}=7)$ & 5 & 2 & 5 & 2 & 6 & 1 & 6 & 1 \\
\hline GII $(n=15)$ & 3 & 12 & 4 & 11 & 4 & 11 & 6 & 9 \\
\hline GIII $(\mathrm{n}=12)$ & 1 & 11 & 1 & 11 & 2 & 10 & 2 & 10 \\
\hline
\end{tabular}

Table 4. UUT tumor risk in relation to NMP22 and cytology

\begin{tabular}{|c|c|c|c|c|c|c|c|c|}
\hline \multirow[t]{2}{*}{ Risk } & \multicolumn{2}{|c|}{$\begin{array}{l}\text { NMP22 } \\
\text { separated } \\
\text { urine }\end{array}$} & \multicolumn{2}{|c|}{$\begin{array}{l}\text { NMP22 } \\
\text { voided } \\
\text { urine }\end{array}$} & \multicolumn{2}{|c|}{$\begin{array}{l}\text { Cytology } \\
\text { separated } \\
\text { urine }\end{array}$} & \multicolumn{2}{|c|}{$\begin{array}{l}\text { Cytology } \\
\text { voided } \\
\text { urine }\end{array}$} \\
\hline & - & + & - & + & - & + & - & + \\
\hline Low $(\mathrm{n}=8)$ & 5 & 3 & 5 & 3 & 6 & 2 & 7 & 1 \\
\hline Medium $(n=8)$ & 2 & 6 & 2 & 6 & 3 & 5 & 4 & 4 \\
\hline $\operatorname{High}(\mathrm{n}=18)$ & 2 & 16 & 3 & 15 & 3 & 15 & 3 & 15 \\
\hline
\end{tabular}

Comparison of Patients with UUT Tumors in Relation to Tumor Stage, Grade and Risk

Only the patients who had UUT tumors were taken into further consideration and analyses. They were divided according to the disease stage and grade.

Table 3 shows the distribution of patients in relation to the disease stage according to the result of the NMP22 test and cytology in separated and voided urine.

The ability of the NMP22 test to detect tumors in the lower stages of disease ( $\mathrm{Ta}$ and $\mathrm{T} 1$ ) was greater; NMP22 was better at detecting T2 stage tumors, while for T3 and T4 stages the results were almost identical. The same analysis was performed for the grade of the disease. NMP22 was better at detecting grade I tumors. It detected grade II tumors with the best accuracy in separated urine, and it was more accurate than cytology at detecting grade III tumors. The patients were divided into three groups according to the degree of risk: those with low risk (Ta GI/GII), medium risk (TaGIII, T1GI/GII) and high risk (T2, T3, T4). The distribution of patients according to the risk in relation to the results of NMP22 and cytology in the separated and voided urine is shown in table 4.

Concerning patients with low and medium risk, tumor detection was better with NMP22 (in separated and voided urine), while with the high risk patients, tumor detection was almost identical in all four methods.

\section{Analysis of the NMP22 Test and Cytology Agreement in Separated and Voided Urine}

The kappa test for agreement was used to compare these four methods. The agreement between NMP22 results for voided and separated urine was kappa $=0.795$ $(p<0.01)$. The agreement between cytology results for voided and separated urine was kappa $=0.710(\mathrm{p}<0.01)$, and the agreement between cytology results for separated urine and NMP22 results for voided urine was kappa = $0.756(\mathrm{p}<0.01)$. The agreement between NMP22 results for voided urine and cytology results for separated urine was kappa $=0.544(\mathrm{p}<0.01)$.

These results indicate that the agreement is higher with the NMP22 test for voided and separated urine as well as cytology for separated and voided urine, while the agreement between NMP22 and cytology is high when it comes to NMP22 and voided urine and cytology and separated urine. The agreement between NMP22 results for voided and cytology results for separated urine was the poorest.

\section{Discussion}

The general characteristics of the test group fully corresponded to test group characteristics described in other reports $[5,6]$. The resulting sensitivity and specificity of the NMP22 test in separated and voided urine is slightly lower compared to the results published so far in the literature, which are about 88 and 96\% [7-9]. The sensitivity of cytological methods was considerably lower than that of NMP22, but the specificity of the cytological methods, whether in voided or separated urine, was higher than with NMP22, which corresponds to the literature findings - sensitivity of NMP22 being 65-78\%, cytology $30-54 \%$, and specificity of NMP22 being $40-70 \%$ and cytology $78-99 \%[10,11]$.

Direct correlation between $\mathrm{T}$ stage tumors and the results of the NMP22 test and urine cytology has been proven in many studies $[7,12,13]$. In our study, NMP22 has proven to be a better marker than cytology when it comes to lower tumor stages. Regarding the higher stages (T3 and T4), cytology and NMP22 show almost identical results. 
Depending on the pathohistological grade of the tumor, the NMP22 test has proven to be superior to cytology not only for the separated but also for the voided urine. In all grades, NMP22 has shown greater number of positive results than cytology $[14,15]$. Looking at the results obtained from the three groups of patients divided according to the level of risk, it is obvious that the most frequent positive results of both the NMP22 test and cytology occur in patients from the high risk study group. NMP22 has proved to be more accurate than cytology in detecting low and medium risk tumors. The connection between tumor stage and grade and the level of risk the patient has and the results of the NMP22 test and cytology is direct and clearly detectable. The connection can be explained by the fact that the higher the tumor grade and stage, the more atypical the tumor cells, and thus the cells are more easily detected by cytology. In other words, the level of proteins in urine detectable by the NMP22 test is higher, so the values of sensitivity range from $15 \%$ with low grade to almost $100 \%$ with high grade, i.e. from 17 to $97 \%$ depending on the $\mathrm{T}$ stage of the disease $[1,12]$. Analysis of agreement showed that the result of NMP22 in separated urine corresponds well with that in voided urine. The same goes for cytological analyses. Given that the examination of any of the two urine samples has almost identical diagnostic accuracy, it allows exemption of patients from invasive sam- pling of urine by catheterization through the bladder and marks the NMP22 test as a quick and simple test for detecting upper urothelium tumors, as well as for monitoring patients treated with conservative surgical methods. The results show that the combination of the NMP22 test and cytology provides higher sensitivity and specificity than when only one of the two tests is done, which is especially important in low grade surface tumors, and also reduces the frequency of endoscopic examinations $[16,17]$.

In conclusion, the NMP22 test has greater sensitivity but lower specificity than urine cytology. In the lower tumor stages, NMP22 is a better detector of the presence of tumors, while in the higher stages it is almost identical to cytology. The combination of NMP22 and cytology has the best ratio of sensitivity and specificity, indicating that this combination is useful when it comes to screening and upper urothelial tumor follow-up. Good result agreement was achieved by the NMP22 test in separated and voided urine, indicating that a noninvasive urine sampling technique can provide us with almost identical results in the upper urothelium tumor diagnosis. Results obtained in this study point out that ureterorenoscopy can be replaced with the NMP22 test during patient follow-up or in the primary diagnostics, especially the screening of regions with endemic nephropathy.

\section{References}

1 Tinyl M, Marberger M: Urinary marker for detecting bladder cancer. Eur Urol 2003;1: 64-70.

-2 Lotan Y, Roehrborn CG: Sensitivity and specificity of commonly available bladder tumor markers versus cytology results of a comprehensive literature review and metaanalyses. Urology 2003;61:109-116.

-3 Mian C, Lodde M, Haitel A, Vigl EE, Marberger M, Pycha A: Comparison of the monoclonal UBC-Elisa test and the NMP22 Elisa test for the detection of urothelial cell carcinoma of the bladder. Urology 2000;50: 223-226.

-4 Siemens DR, Morales A, Johnston B, Emerson L: A comparative analysis of rapid urine tests for the diagnosis of upper urinary tract malignancy. Can J Urol 2003;10:1754-1758.

-5 Oosterlinck W, Solsona E, van der Meijden APM, Sylvester R, Bohle A, Rintala E, Lobel $B$ : EAU guidelines on diagnosis and treatment of upper urinary tract transitional cell carcinoma. Eur Urol 2004;46:147-154.

-6 Munoz J, Ellison LM: Upper tract urothelial neoplasm: incidence and survival the last 2 decades. J Urol 2000;164:1523.
7 van Rhijn BWG, van der Poel HG, van der Kwast TH: Urine markers for bladder cancer surveillance: a systematic review. Eur Urol 2005;47:736-748.

8 Chahal R, Darshane A, Browing AJ, Sundaram SK: Evaluation of the clinical value of urinary NMP 22 as a marker in the screening and surveillance of transitional cell carcinoma of the urinary bladder. Eur Urol 2001;40: 415-421.

-9 Ponsky L, Harma S, Pandrangi L, Kedia S, Nelson D, Agrawal A, Zippe C: Screening and monitoring for bladder cancer: refining the use of NMP22. J Urol 2001;166:75-78.

10 Tritcheler S, Scharf S, Karl A, Tilki D, Knuechel R, Hartmann A, Stief CG, Zaak D: Validation of the diagnostic value of NMP22 BladderChek Test as a marker for bladder cancer by photodynamic diagnosis. Eur Urol 2007;51:403-408.

11 Giannopoulos A, Manousakas T, Mitropoulos D, Botsoli-Stergiou E, Constantinides C, Giannopoulou M, et al: Comparative evaluation of the BTAstat test, NMP22, and voided urine cytology in the detection of primary and recurrent bladder tumors. Urology 2000;55:871-875.
12 Bian Y, Ehya H, Bagley DH: Cytologic diagnosis of upper urinary tract neoplasms by ureteroscopic sampling. Acta Cytol 1995;39: 733-740.

13 Nabi G, Greene DR, O’Donnell M: How important is urinary cytology in the diagnosis of urological malignancies? Eur Urol 2003; 43:632-636.

14 Shariat SF, Marberger MJ, Lotan Y, SanchezCarbayo M, Zippe C, Ludecke G, et al: Variability in the performance of nuclear matrix protein 22 for the detection of bladder cancer. J Urol 2006;176:919-926.

$\checkmark 15$ Menedez V, Filella X, Alcover JA, Molina R, Mallafre JM, Ballesta AM, et al: Usefulness of urinary nuclear matrix protein 22 (NMP22) as a marker for transitional cell carcinoma of the bladder. Anticancer Res 2000;20:1169-1172.

16 Konety BR, Getzenberg RH: Urine based marker of urological malignancy. J Urol 2001;165:600-611.

17 Grossman H, Messing E, Soloway M, et al: Detection of bladder cancer using a point-of care proteomic assay. JAMA 2005;293:810816. 